\title{
Prevalence of folate and vitamin B12 deficiency in Mexican children aged 1 to 6 years in a population-based survey
}

Lucía Cuevas-Nasu, MSc, (I) Verónica Mundo-Rosas, MSc, (') Teresa Shamah-Levy, MSc, (1) Ignacio Méndez-Gómez Humaran, MSc, (2) Marco Antonio Ávila-Arcos, BSc, (1) Ma. del Rosario Rebollar-Campos, Lab Tech, ${ }^{(1)}$ Salvador Villalpando, PhD.(I)

\author{
Cuevas-Nasu L, Mundo-Rosas V, Shamah-Levy T, \\ Méndez-Gómez Humaran I, Ávila-Arcos MA, \\ Rebollar-Campos MR, Villalpando S. \\ Prevalence of folate and vitamin $B \mid 2$ deficiency \\ in Mexican children aged I to 6 years \\ in a population-based survey. \\ Salud Publica Mex 20 I2;54: I I6-I 24.
}

\begin{abstract}
Objective. To describe the magnitude and distribution of folate and vitamin BI2 deficiency in Mexican children. Materials and methods. Folate and vitamin BI2 serum concentrations were measured in a probabilistic sample of 2099 children. Adjusted prevalence, mean concentrations and relevant associations were calculated based on series of logistic and linear regression models. Results. The overall prevalence of folate and vitamin $\mathrm{BI} 2$ deficiency were $3.2 \%$ and $7.7 \%$, respectively. The highest prevalence of folate was found in the 2-year-old (7.9\%), and of vitamin BI2 in the I year-old $(9.1 \%)$ groups. Being a beneficiary of the fortified milk program Liconsa was protectively associated with serum folate $(p=0.00 \mathrm{I})$ and daily Intake of milk with vitamin BI2 $(p=0.002)$ concentrations. Conclusions. We describe the magnitude of folate and vitamin BI2 deficiencies in Mexican children. The deficiency of both vitamins in children under 2 years old is a moderate public health problem in Mexico.
\end{abstract}

Key words: Vitamin BI2 deficiency; folate deficiency; children; probabilistic surveys; Mexico
Cuevas-Nasu L, Mundo-Rosas V, Shamah-Levy T, Méndez-Gómez Humaran I, Ávila-Arcos MA,

Rebollar-Campos MR, Villalpando S.

Distribución de la prevalencia de deficiencia de folato y vitamina B I 2 en niños mexicanos de I a 6 años de edad. Encuesta con base poblacional.

Salud Publica Mex 2012;54:I I6-I 24.

\section{Resumen}

Objetivo. Describir la magnitud de la deficiencia de folato y vitamina BI2 en niños mexicanos. Material y métodos. Se midieron las concentraciones séricas de folatos y vitamina BI 2 en una muestra probabilística de 2099 niños. Se calcularon prevalencias ajustadas, medias de las concentraciones $y$ las asociaciones relevantes mediante una serie de modelos de regresiones logísticas y lineales. Resultados. La prevalencia global de deficiencia de folatos y vitamina BI2 fueron $3.2 \%$ y $7.7 \%$, respectivamente. La prevalencia más alta de folatos se encontró en el grupo de 2 años (7.9\%) y de la vitamina BI2 en los de I año de edad (9.1\%). Ser beneficiario del programa de leche fortificada Liconsa estuvo asociado de manera protectora con el folato serico $(p=0.00 \mathrm{I})$ y la ingestión diaria de leche con la de vitamina $B I 2(p=0.002)$. Conclusiones. La deficiencia de ambas vitaminas, en los niños menores de dos años, es un problema de salud pública de magnitud moderada en México.

Palabras clave: deficiencia de vitamina $\mathrm{B}$ I2; deficiencia de folatos; niños; encuesta probabilística, México

(I) Instituto Nacional de Salud Pública.Cuernavaca, Morelos, México

(2) Centro de Investigación en Matemáticas, A. C. Aguascalientes, México

Received on: June 3, 20II - Accepted on: January 31, 2012 Corresponding author: MSc Verónica Mundo-Rosas. Instituto Nacional de Salud Pública. Av. Universidad 655 Col. Santa María Ahuacatitlán. 62100 Cuernavaca, Morelos, México. E-mail: vmundo@insp.mx 
$\mathrm{D}_{\mathrm{f}}$ ficiency of micronutrients is still one of the most frequent nutritional problems worldwide. The lack of access to a varied diet including animal foods, grains, fruits, and vegetables, is the recurrent cause of deficiency, given those are the most important sources of micronutrients. ${ }^{1}$

Folate deficiency is related mainly to a low intake of green leafy vegetables and legumes and meat. ${ }^{2}$ This deficiency is associated with megaloblastic anemia..$^{3-5}$ During pregnancy, it is linked to an increased risk of low birth weight and neural tube defects, ${ }^{6,7}$ and it is also associated with stunting. ${ }^{8,9}$

Vitamin B12 deficiency is more frequent in population with a poor or inadequate diet of animal foods. ${ }^{10}$ Other causes of this deficiency include: intestinal parasitosis in low-income population, ${ }^{11}$ Helycobacter pylori infections, ${ }^{12}$ and atrophic gastritis in older adults (due to lack of intrinsic factor production). ${ }^{13}$ Strict vegetarian diets may be associated with vitamin B12 deficiency, both, in the mother and in the newborn, because the demand for this vitamin increases during pregnancy and lactation. ${ }^{14}$ Clinical manifestations of vitamin B12 deficiency include megaloblastic anemia which is undistinguishable from that produced by folate deficiency. Vitamin B12 is also crucially involved in the proliferation, maturation, and regeneration of neural cells ${ }^{15}$ therefore, its deficiency causes memory loss, dementia, and depression ${ }^{16}$ as well as cardiovascular disease $\mathrm{e}^{17,18}$ and cerebrovascular ischemia. ${ }^{19}$

There is very little population-based information regarding folate and vitamin B12 deficiencies, although its prevalence could be very high worldwide. ${ }^{20}$ Folate deficiency is among the five micronutrient deficiencies targeted for population-based interventions, ${ }^{1}$ especially because of its role in the reduction of the incidence of neural tube defects. ${ }^{21,22}$ Also, has been documented that about $40 \%$ of Latin American children and adults suffer from vitamin B12 deficiency or have marginally low serum concentrations. The prevalence of vitamin B12 depletion and marginal deficiency is even higher in Kenyan school children (70\%) and Indian preschool children $(80 \%))^{23}$

The recent review by WHO showed that the majority of data on the prevalence of folate and vitamin B12 deficiencies are derived from local surveys, but these and national survey data from a few countries suggest that deficiencies of both of these vitamins may be a public health problem. ${ }^{24}$

In Mexico, there are few studies documenting the deficiency of vitamin B12 and folate. ENN-99 (Encuesta Nacional de Nutrición 1999) was a probabilistic survey, representative of the national, regional, as well as urban and rural levels in Mexico. ENN-99 was conducted on a sample of almost 18000 households. ${ }^{25}$ Overall folate deficiency in ENN-99 was 7.3\% in children under 12 years-of-age, the highest prevalence corresponding to children younger than 2 years and those aged 3 to 4 years $\left(8.8 \%\right.$ and $11.2 \%$, respectively). ${ }^{26}$ Besides in a sample of children younger than 2 years old, representative of beneficiaries of health care services provided by the Mexican Institute of Social Security (IMSS) the prevalence of folate deficiency in children was 10\% in urban and $8 \%$ in rural area, respectively. ${ }^{27}$

Some studies have measured the magnitude of vitamin B12 deficiency in children under 5 years old, those had reported prevalence of $8 \%$ in six rural communities at central region in Mexico. ${ }^{28}$ Others reported prevalence of $30 \%$ in a subsample of data from the National Nutrition Survey 1999 (ENN-99). ${ }^{29}$ In both cases, these studies do not represent the national population.

The aim of this analysis is to describe the magnitude and distribution of folate and vitamin B12 deficiency in Mexican children aged 1 to 6 years, and to identify some associated sociodemographic and dietary determinants using data derived from the National Health and Nutrition Survey 2006 (ENSANUT-2006). Data from this study could help to plan public health strategies and policies focused on the control and reduction of these micronutrient deficiencies.

\section{Materials and methods}

The National Health and Nutrition Survey conducted in Mexico (ENSANUT-2006) was a probabilistic, crosssectional, stratified cluster sample study representative of the national, regional, and state levels, and of urban and rural areas. Sampling methodology was previously published. ${ }^{30}$ The ENSANUT-2006 was more extensive than previous surveys. It covered more health and nutrition problems (including the deficiency of some nutrients such as vitamin B12) which broaden the populations studied in previous surveys. ENSANUT had the power to make distinctions between geographic regions, and urban and rural area of residence.

The information collected includes socio-demographic, health and nutrition conditions; anthropometry and food consumption in all participants, included information of 11685 children aged 1 to 6 years. Blood samples were obtained from a systematic sub-sample of 2099 children to document the vitamins deficiencies.

Statistical analysis and model based estimators were carried out to assess a possible selection bias, using reference variables like height, weight and the socioeconomic index. There were not differences compared the selected sub-sample and the overall sample of the survey. 


\section{Blood sample collection, preparation, and preservation}

Blood samples were drawn from the antecubital vein and collected in evacuated tubes (Vacutainer vacuum tubes, Beckton Dickinson Inc). Blood was centrifugated in situ at $2500 \mathrm{~g}$ in a portable centrifuge (Hettich). Serum was stored in cryotubes covered with aluminum foil to preserve them from light and kept in liquid nitrogen to be transported to the Nutrition laboratory at the National Institute of Public Health in Cuernavaca, Mexico.

\section{Laboratory methods}

Both serum folate and vitamin B12 were released from proteins using sodium hydroxide, dithiothreitol, and potassium cyanide, and transformed into cyanocobalamin and stable folates. Their concentrations were measured by competitive enzymatic immunoassays in a $\mathrm{TOSOH}$ automated immunoanalyzer.

\section{Definition of variables}

\section{a) Folate and vitamin B12 deficiencies}

Children with serum concentrations of vitamin B12 below 203pg/mL and of folate below $4 \mathrm{ng} / \mathrm{mL}$ were categorized as deficient. ${ }^{20}$

\section{b) Sociodemographic variables}

A questionnaire administered to the mother or guardian of the child collected socioeconomic and household information. A socioeconomic status index (SES) was constructed through a main components analysis based on the household characteristics and family assets: floor covering, piped water, owning of radio, TV set, computer, telephone, refrigerator, washing machine, stove and automobile. The first component accounted for $46 \%$ of the total variance. The resulting standardized factor was divided into tertiles to categorize three socioeconomic status groups: low, medium and high.

\section{c) Dietary information}

Dietary data were obtained through a semiquantitative food frequency questionnaire for the seven days previous to the interview. The questionnaire included 102 food items and was administered by personnel trained and standardized on data collection. ${ }^{31}$

Data on food intake were transformed into energy and nutrients intake, using a food composition table compiled by INSP. ${ }^{32}$ Details about the processing of dietary information were previously published. ${ }^{33}$ Mean daily folate and vitamin B12 intakes were estimated and food groups that furnished those vitamins were identified and expressed as $100 \mathrm{~g}$ of daily intake.

\section{d) Residence area}

In Mexico, the breakdown by size of locality (urban or rural) is directly related to the principle that smaller towns are reduced in development conditions. According to the National Institute of Statistics and Geography (INEGI, for its acronym in Spanish), localities with 2500 inhabitants or more were considered as urban; otherwise were categorized as rural..$^{34}$

\section{e) Region of residence}

According to the ENSANUT sample frame, the states of the country were divided into four regions: North, Center, Mexico City, and South. ${ }^{30}$ Mexico City was excluded from this analysis because of the small number of available samples.

\section{f) Food assistance programs}

A child was defined as affiliated with a public food assistance program when the mother or guardian declared that he or she received food or micronutrient supplements from programs as such Oportunidades, Liconsa or others.

\section{g) Indigenous ethnicity}

Indigenous ethnicity was defined when a family member spoke an indigenous language.

\section{Statistical analysis}

Data are described as frequencies and by confidence intervals $(95 \% \mathrm{CI})$. Prevalence for folate and vitamin B12 deficiencies and the adjusted means of the serum concentration of both vitamins were estimated and stratified by age, sex, locality, geographic region, socioeconomic status and indigenous ethnicity. Linear regression models were constructed to assess the effect of nutrient intake, food assistance programs and indigenous ethnicity, adjusted by age sex and sociodemographic variables on folate and vitamin B12 serum concentrations. Interaction terms between folate and vitamin B12 were introduced in both vitamins models.

All analysis procedures were carried out using corrections for the sample. The original expansion factors of this survey were recalculated using a ratio calibration 
procedure, to improve the population representativeness for estimators at the national level.

The analysis was carried out using the Stata V10.1 software; adjustment for the sample design was performed using the module for complex samples SVY and the SPSS V15.0 software.

\section{Ethical aspects}

The protocol was approved by the Research, Ethics and Biosecurity Committees. Written informed consent was signed-up by the mother or guardian of the child before participation in the survey.

\section{Results}

This sample of 2099 children aged 1 to 6 years with serum folate and vitamin B12 determinations represents approximately 6 million Mexican children.

\section{Folic acid deficiency}

The overall mean of serum folate concentration was 12.5 $\mathrm{ng} / \mathrm{mL}(95 \% \mathrm{CI} 12.1,12.9)$ and the overall prevalence of folate deficiency was $3.2 \%$ (Table I). The highest prevalence was in children aged 1 to 2 years $(4.3 \%$ and $7.9 \%$, respectively) and it decreased with age down to $2.4 \%$ in children aged 6 years.

Table I

Prevalence of folic acid deficiency in Children aged I to 6 Years* by age group, sex, area of Residence, Region, ANd indigenous status. Ensanut 2006, Mexico

\begin{tabular}{|c|c|c|c|c|c|c|}
\hline \multicolumn{7}{|c|}{ Folic acid } \\
\hline \multirow[t]{2}{*}{ Variables } & \multirow{2}{*}{$\begin{array}{l}\text { Sample } \\
\qquad N\end{array}$} & \multirow{2}{*}{$\begin{array}{c}\text { Expanded } \\
\text { (thousands) } \\
N\end{array}$} & \multicolumn{2}{|c|}{$\begin{array}{l}\text { Deficiency } \\
\text { (<4ng/mL) }\end{array}$} & \multicolumn{2}{|c|}{ Serum concentration } \\
\hline & & & $\%$ & $95 \% \mathrm{Cl}$ & Medium & $95 \% \mathrm{Cl}$ \\
\hline National & 2099 & 6039.5 & 3.2 & $(1.4,4.9)$ & 12.50 & $(12.1,12.9)$ \\
\hline From I to 5 years of age & 1051 & 3628.6 & 3.6 & $(0.9,6.2)$ & 12.65 & $(12.1,13.2)$ \\
\hline 1 & 156 & 726.6 & 4.3 & $(0.0,8.6)$ & 12.79 & $(I I .5,14.1)$ \\
\hline 2 & 221 & 738.8 & 7.9 & $(0.0,19.2)$ & 12.17 & $(10.8,13.5)$ \\
\hline 3 & 309 & 1030.0 & 0.7 & $(0.0,1.6)$ & 12.74 & $(11.6,13.8)$ \\
\hline 4 & 365 & 1133.2 & 2.8 & $(0.5,5.2)$ & 12.77 & $(11.9,13.6)$ \\
\hline 5 & 534 & I237. I & 2.9 & $(0.9,4.9)$ & 12.24 & $(11.6,12.9)$ \\
\hline 6 & 514 & 1173.8 & 2.4 & $(0.8,3.9)$ & 12.30 & $(11.6,13.0)$ \\
\hline \multicolumn{7}{|l|}{ Sex } \\
\hline Boys & 1064 & 3202.5 & 4.1 & $(I . I, 7.1)$ & 12.19 & $(11.6,12.8)$ \\
\hline Girls & 1035 & 2837.0 & 2.1 & $(1.0,3.3)$ & 12.83 & $(12.3,13.3)$ \\
\hline
\end{tabular}

Area of residence

\begin{tabular}{lrrrrrrr} 
Urban & 931 & 3574.2 & 3.5 & $(0.8,6.2)$ & 12.48 & $(I 1.9,13.1)$ \\
\hline Rural & 1168 & 2465.3 & 2.8 & $(I .0,4.6)$ & $12.5 \mid$
\end{tabular}

Region

\begin{tabular}{lrrrrrrrr} 
Northern & 376 & 1328.9 & 0.9 & $(0.0,2.0)$ & 13.58 & $(I 2.7,14.4)$ \\
\hline Center & 678 & 1797.8 & 2.9 & $(1.2,4.6)$ & 12.43 & $(I I .8,13.1)$ \\
\hline Southern & 1045 & 2912.8 & 4.4 & $(1.0,7.8)$ & 12.04 & $(I 1.4,12.7)$ \\
\hline Indigenous ethnicity & 206 & 555.8 & 4.5 & $(0.6,8.3)$ & 11.53 & $(I 0.4,12.6)$
\end{tabular}

* Sample size 2 099, weighted cases: (thousands=6039.5) 
Prevalence of folate deficiency was higher in boys (4.1\%) than in girls (2.1\%); in urban (3.5\%) than in rural $(2.8 \%)$, and in the Southern (4.4\%) than in the Northern $(0.9 \%)$ region. Folate deficiency was also higher in indigenous children $(4.5 \%)$ compared with the national prevalence $(3.2 \%)$. However, none of these differences were significant.

In a multiple linear regression model having folate concentrations as the dependent variable, the intake of vegetables (more than $100 \mathrm{~g} /$ day) (coefficient 0.79, $p=0.09$ ) and being beneficiary of the Fortified Milk program (Liconsa) (coefficient 1.72, $p=0.004$ ) were positively associated with serum folate concentration. Living in the Center or Southern regions was negatively associated with serum folate concentration (coefficients 1.37 and 1.7, $\mathrm{p}=0.014$ and $\mathrm{p}=0.004$, respectively). The interaction between folate intake and vitamin B12 was not significant (Table III).

\section{Vitamin B I 2 deficiency}

The overall mean concentration of vitamin B12 was 510.2 $\mathrm{pg} / \mathrm{mL}(95 \% \mathrm{CI} 487.9,532.6)$, and overall prevalence deficiency was $7.7 \%$. The prevalence of vitamin B12 deficiency varied in a non-systematic manner between $5.5 \%$ in children aged 3 years and $10.6 \%$ in those aged 6 years. The prevalence was highest in children from the Southern region (12.1\%) and in children of indigenous ethnicity $(14.2 \%)$, and lowest in the Northern region $(3.4 \%)$, and non-indigenous children and compared with the national prevalence $(7.7 \%)$ (Table II).

In a multiple linear regression model with vitamin B12 serum concentration as dependent variable, the dairy foods intake (more than $100 \mathrm{~mL}$ per day) was found to be positively associated with the serum concentration of vitamin B12 (coefficient 70.0, p=0.002). In addition, belonging to medium or high socioeconomic

Table II

Prevalence of Vitamin B I 2 deficiency in Children aged I to 6 Years by Age group, Sex, ARea of residence, region, AND indigenous status. Ensanut 2006, Mexico

\begin{tabular}{|c|c|c|c|c|c|c|}
\hline \multirow[t]{2}{*}{ Variables } & \multirow{2}{*}{$\begin{array}{c}\text { Sample } \\
\text { N }\end{array}$} & \multirow{2}{*}{$\begin{array}{c}\text { Expanded } \\
\text { (thousands) } \\
N\end{array}$} & \multicolumn{2}{|c|}{ Deficiency (<203pg/mL) } & \multicolumn{2}{|c|}{ Serum concentration } \\
\hline & & & $\%$ & $95 \% \mathrm{Cl}$ & Medium & $95 \% \mathrm{Cl}$ \\
\hline National & 2040 & 5950.6 & 7.7 & $(5.3,10.0)$ & 510.22 & $(487.9,532.6)$ \\
\hline From I to 5 years of age & 1007 & 3568.9 & 7.3 & $(4.2,10.4)$ & 516.29 & $(489.3,543.3)$ \\
\hline 1 & 151 & 720.3 & 9.1 & $(5.0,22.1)$ & 481.88 & $(427.8,535.9)$ \\
\hline 2 & 208 & 719.9 & 5.9 & $(4.2,14.1)$ & 550.62 & $(493.4,607.8)$ \\
\hline 3 & 296 & 1003.8 & 5.5 & $(3.2,12.7)$ & 524.89 & $(485.7,564.1)$ \\
\hline 4 & 352 & II 24.8 & 8.6 & $(3.9,14.2)$ & 508.67 & $(453.0,564.3)$ \\
\hline 5 & 528 & I224.I & 6.0 & $(4.4,11.5)$ & 542.55 & $(485.9,599.2)$ \\
\hline 6 & 505 & 1157.7 & 10.6 & $(6.9,15.6)$ & 457.36 & $(422.1,492.6)$ \\
\hline \multicolumn{7}{|l|}{ Sex } \\
\hline Boys & 1042 & 3178.2 & 6.9 & $(3.7,10.0)$ & 519.12 & $(488.5,549.8)$ \\
\hline Girls & 998 & 2772.4 & 8.6 & $(5.3,11.9)$ & 500.03 & $(469.6,530.5)$ \\
\hline
\end{tabular}

Area of residence

\begin{tabular}{lrrrrrrrr} 
Urban & 916 & 3543.5 & 5.9 & $(2.6,9.2)$ & 536.27 & $(503.9,568.6)$ \\
\hline Rural & 1124 & 2407.1 & 10.2 & $(7.1,13.3)$ & 471.89 & $(444.0,499.8)$
\end{tabular}

Region

\begin{tabular}{lrccccc} 
Northern & 373 & 1323.1 & 3.4 & $(0.7,6.2)$ & 563.79 & $(513.3,614.2)$ \\
\hline Center & 641 & 1747.3 & 3.6 & $(1.6,5.7)$ & 535.95 & $(506.2,565.8)$ \\
\hline Southern & 1026 & 2880.2 & 12.1 & $(7.7,16.4)$ & 470.01 & $(436.4,503.7)$ \\
\hline Indigenous ethnicity & 203 & 548.8 & 14.2 & $(7.2,21.1)$ & 364.18 & $(330.3,398.1)$
\end{tabular}

* Sample size 2 099, weighted cases: (thousands=6039.5) 
Table III

MULTIPLE LINEAR REGRESSION MODEL WITH FOLATE CONCENTRATION AS DEPENDENT VARIABLE, * ADJUSTING FOR SOCIODEMOGRAPHIC AND FOOD INTAKE VARIABLES IN MEXICAN CHILDREN AGED I TO 6 YEARS. Ensanut 2006, Mexico

\begin{tabular}{|c|c|c|c|c|}
\hline Covariables & Coefficient & Standard error & $p$ value & $95 \% \mathrm{Cl}$ \\
\hline SES Medium $\ddagger$ & -0.28 & 0.50 & 0.581 & $(-I .26,0.7 \mid)$ \\
\hline SES High ${ }^{\ddagger}$ & -0.04 & 0.62 & 0.945 & $(-1.25,1.17)$ \\
\hline Beneficiary of Oportunidades & 0.35 & 0.50 & 0.480 & $(-0.63,1.33)$ \\
\hline Beneficiary of Liconsa & 1.72 & 0.52 & 0.001 & $(0.71,2.73)$ \\
\hline Center Region ${ }^{\S}$ & -1.37 & 0.56 & 0.014 & $(-2.46,-0.27)$ \\
\hline Southern Region $\S$ & -1.70 & 0.59 & 0.004 & $(-2.85,-0.55)$ \\
\hline Area Rural & 0.53 & 0.47 & 0.262 & $(-0.40,1.45)$ \\
\hline Sex Boy & -0.59 & 0.35 & 0.090 & $(-1.28,0.09)$ \\
\hline Age (years) & -0.19 & 0.12 & 0.128 & $(-0.43,0.05)$ \\
\hline Indigenous status & -0.80 & 0.67 & 0.228 & $(-2.11,0.50)$ \\
\hline Folate intake & 0.00 & 0.00 & 0.357 & $(-0.004,0.010)$ \\
\hline Vitamin BI2 intake & 0.02 & 0.38 & 0.952 & $(-0.72,0.76)$ \\
\hline Folate X Vitamin BI2 & 0.00 & 0.00 & 0.710 & $(0,0)$ \\
\hline Grains intake (>100g/d) & 0.69 & 0.53 & 0.188 & $(-0.34,1.73)$ \\
\hline Legumes intake $(>100 \mathrm{~g} / \mathrm{d})$ & 0.20 & 0.48 & 0.673 & $(-0.74,1.14)$ \\
\hline Vegetables intake $(>100 \mathrm{~g} / \mathrm{d})$ & 0.79 & 0.47 & 0.092 & $(-0.13,1.72)$ \\
\hline Constant & 13.03 & 0.89 & 0.000 & $(\mathrm{II} .29, \mathrm{I4.77})$ \\
\hline $\begin{array}{l}* \mathrm{n}=201 \mathrm{I} \\
\text { ‡ Dummy variable: SES Low } \\
\text { § Dummy variable: Northern Region }\end{array}$ & & & & \\
\hline
\end{tabular}

status was positively associated with the serum concentration of vitamin B12 (coefficients 98.7 and 88.9, respectively, $p=0.001$ ).

Being of indigenous ethnicity was negatively associated with the serum concentrations of vitamin B12 (coefficient 48.2, $p=0.04$ ) (Table IV).

\section{Discussion}

We describe herein the magnitude and distribution of the prevalence of folate and vitamin B12 deficiency in a population sample of Mexican children younger than 6 years.

The observed national prevalence of $7.7 \%$ for vitamin B12 and 3.2\% for folate deficiencies represents more than 456000 and 193000 children younger than 6 years, suffering from these vitamin deficiencies in Mexico. The national overall prevalence of folate deficiency was relatively low, although the groups of 1 and 2-year-old children had the highest prevalence $(4.3 \%$ and $7.9 \%$, respectively).

While the national prevalence of vitamin B12 was always above $5 \%$. Such prevalence, close to $5 \%$, should be considered as a public health problem according to the WHO Technical Consultation on folate and vitamin $\mathrm{B} 12 .{ }^{20}$

Results also indicate that the highest prevalence of folate and vitamin B12 deficiency have seen in the most vulnerable population: children younger than 2 years old, from indigenous origin, and living in the Southern region, known for its poor economic development in Mexico.

The low serum concentrations of vitamin B12 and folate, might be associated with the low body reserves of newborns at birth. In developing countries, maternal deficiency of vitamin B12 is frequent during pregnancy due to poor or inadequate intakes of animal foods. For small children, dietary intake of both vitamins is limited during the weaning period because, frequently, weaning foods offered is reduced to a limited variety of foods with a low content of micronutrients. This, in time, critically reduces their body stores and serum levels.

Also, the high prevalence of B12 deficiency in school children might be associated with an inadequate intake or a low absorption of the vitamin because of parasitic or recurrent bacterial infections. ${ }^{35-37}$ 
Table IV

Multiple LiNEAR REgRession MOdel With VITAMIN B I 2 CONCENTRATION AS DEPENDENT VARIABLe,* ADJUSTING FOR SOCIODEMOGRAPHIC AND FOOD INTAKE VARIABLES IN MEXICAN CHILDREN AGED I TO 6 YEARS. Ensanut 2006, MeXico

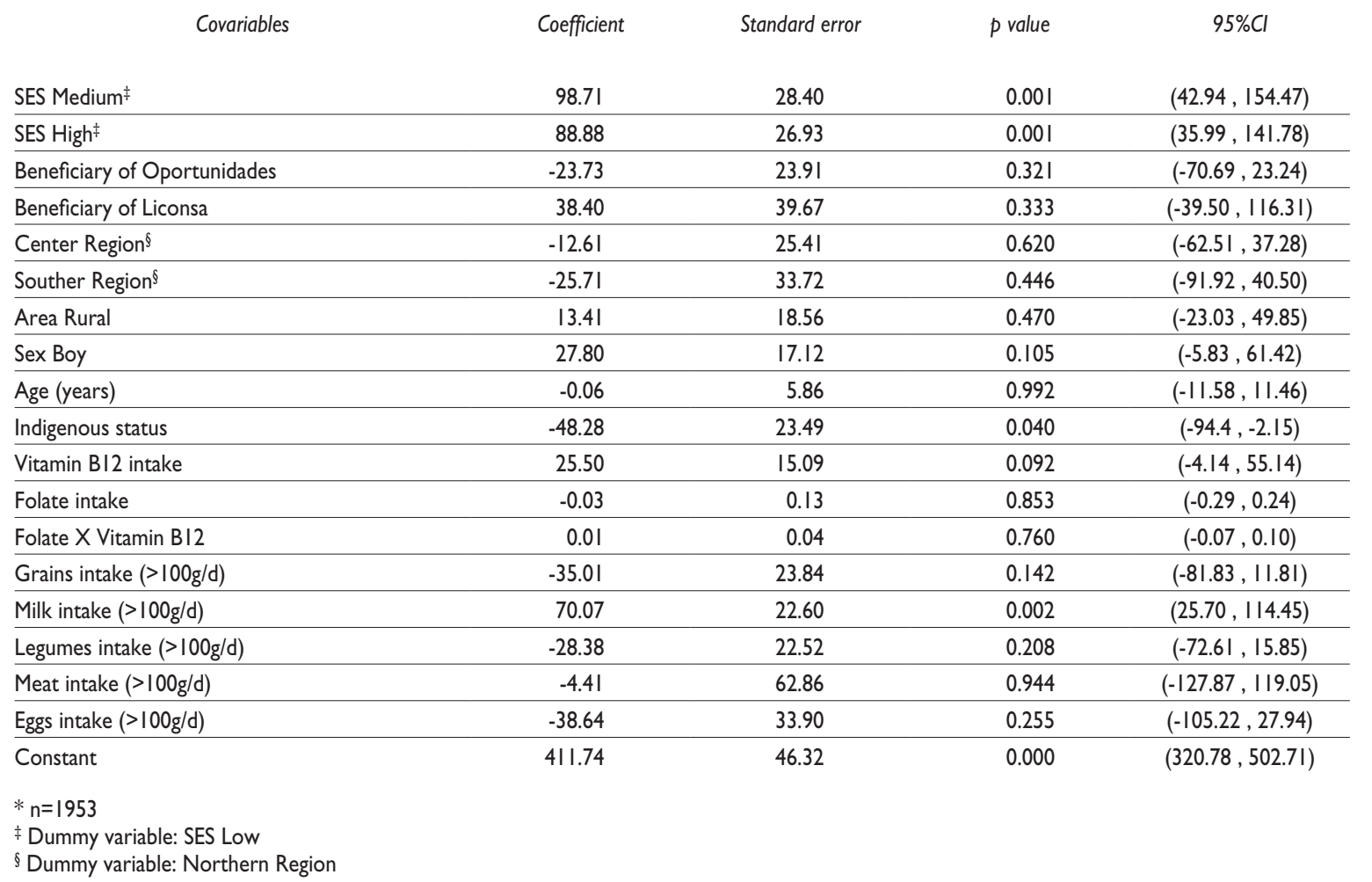

The presence of fortification programs, population group, indicators and cut-off points used to assess folate and vitamin B12 status in countries with similar levels of development as such Guatemala, ${ }^{38}$ Costa Rica ${ }^{39}$ and Venezuela ${ }^{40}$ were not homogeneous and precluded us to make comparisons with the findings reported. Comparability with other population-based surveys in Mexico and the estimation of trends are difficult as well. In the 1999 National Nutrition Survey (ENN-1999) ${ }^{26}$ folate was measured in red blood cells using a microbiological assay, whereas in the ENSANUT-2006, folate concentration was measured in serum using an immune assay. On these grounds the comparison is not valid because red blood cell folate is an indicator of body stores while serum values indicate recent dietary intake. However, repeated plasma folate measurements over time reflect trends in folate status. ${ }^{41}$ In 1999, the prevalence of low folate stores in children under $5 y$ of age was low $(10 \%)$, but we are not able to assess whether the 2006 preva- lence of low serum folate in the same age group (3.6\%) represent a change.

Is also difficult to quantify the change in the magnitude of the deficiency of vitamin B12 because published studies are based on specific groups or populations who do not represent the national population. However, the prevalence reported by Allen L. in the preschool age group from a subsample of the National Nutrition Survey 1999 (ENN-99) was 30\% ${ }^{29}$ compared with $7 \%$ in the present study, suggests a decrease in the magnitude of this problem.

For more than a decade, Mexico has implemented targeted interventions in addressing nutrient deficiencies in children: The voluntary fortification of maize and wheat flour with iron and folic acid; ${ }^{42}$ Oportunidades Human Development Program that distributes a nutritional supplement (suplemento Nutrisano) and The Social Milk Supply Program (LICONSA) that provides fortified milk containing nutrients deficient in 
the Mexican diet, including folic acid and vitamin B12. Without a doubt, these interventions have a positive effect on reducing these vitamins deficiencies in children, however, the impact of these interventions in reducing folate and vitamin B12 deficiencies has not been evaluated. We found in this study that being beneficiary of the Liconsa program was associated with higher serum concentrations of folate, and the intake of more than $100 \mathrm{~mL}$ of dairy products was positively associated with serum concentrations of vitamin B12.

This study contributes to generate information on the magnitude of the deficiency of both vitamins, since there are very few available publications documenting folate and vitamin B12 deficiencies in children at preschool age, one of the most affected group. ${ }^{43}$ The current strategies for reducing and controlling micronutrient deficiencies should thus be reexamined. Particular attention must be paid to the content of folic acid and vitamin B12 of the food or supplements distributed by food assistance programs like Oportunidades and Liconsa.

Declaration of conflict of interests. The authors declare that they have no conflict of interests.

\section{References}

I. The Micronutrient Initiative. Investing in the future. A united call to action on vitamin and mineral deficiencies. Global report 2009. Pp. I-44. [Accessed 2010 September 20]. Available at: http://www. unitedcalltoaction.org/documents/lnvesting_in_the_future.pdf 2. Carmel R. Discussion: Causes of vitamin $B / 2$ and folate deficiencies. Food Nutr Bull. 2008 ;29(2 Suppl):S35-S37.

3. Al Khatib L, Obeid O, Sibai AM, Batal M, Adra N, Hwalla N. Folate deficiency is associated with nutritional anaemia in Lebanese women of childbearing age. Public Health Nutr 2006; 9:921-927.

4. Haidar J. Prevalence of Anaemia, Deficiencies of Iron and Folic Acid and Their Determinants in Ethiopian Women. J Health Popul Nutr 2010;28:359-368.

5. Metz J. A high prevalence of biochemical evidence of vitamin $\mathrm{B} / 2$ or folate deficiency does not translate into a comparable prevalence of anemia. Food Nutr Bull 2008; 29(2 Suppl):S74-85.

6. Daly LE, Kirke PM, Molloy A, Weir DG, Scott JM. Folate levels and neural tube defects. Implications for prevention. JAMA 1995;274: I698-I702.

7. Rodríguez-Morán M, Guerrero-Romero JF, Parra-Quezada M, SeguraPineda MJ, Levario-Carrillo M, Sotelo-Ham El. Deficiencia de folatos y su asociación con defectos de cierre del tubo neural en el norte de México. Salud Publica Mex 1998:40:474-480.

8. Villalpando S, Latulippe ME, Rosas G, Irurita J, Picciano MF, O'Connor DL. Milk folate but not milk iron concentrations may be inadequate for some infants in a rural farming community in San Mateo, Capulhuac, Mexico. Am J Clin Nutr 2003; 78: 782-789.

9. Matoth Y, Zehavi I, Topper E. Klein T. Folate nutrition and growth in infancy. Arch Dis Child 1979; 54: 699-702.

10. Allen LH. Causes of vitamin BI2 and folate deficiency. Food Nutr Bull. $2008 ; 29$ (2 Suppl):S20-34.

II. Bjorke-Monsen AL, Refsum H, Markestad T, Ueland PM.

Cobalamin status and its biochemical markers methylmalonic acid and homocysteine in different age groups from 4 days to 19 years. Clin Chem 2003;49:2067-2075.

12. Kaptan K, Beyan C, Ural AU, Cetin C, Avcu F, Gülsen M, et al. Helicobacter pylori - is it a novel causative agent in Vitamin BI2 deficiency? Arch Intern Med 2000; 160: 1349-I353.

I3. Sipponen P, Laxen F, Huotari K, Harkonen M. Prevalence of low vitamin $\mathrm{BI} 2$ and high homocysteine in serum in an elderly male population: association with atrophic gastritis and Helicobacter pylori infection. Scand J Gastroenterol 2003; 38: 1209-1216.

14. Allen LH. Vitamin BI2 metabolism and status during pregnancy, lactation and infancy. Adv Exp Med Biol 1994;352: I73-186.

I5. Herrmann W, Obeid R. Causes and Early Diagnosis of Vitamin BI2 Deficiency. Dtsch Arztebl Int 2008; 105: 680-685.

16. Selhub J, Bagley LC, Miller J, Rosenberg IH. B vitamins, homocysteine, and neurocognitive function in the elderly. Am J Clin Nutr 2000;7I:

6I4S-620S.

I7. Verhoef P, Kok FJ, Kruyssen DA, Schouten EG, Witteman JC, Grobbee $\mathrm{DE}$, et al. Plasma total homocysteine, $\mathrm{B}$ vitamins, and risk of coronary atherosclerosis. Arterioscler Thromb Vasc Biol 1997; 17: 989-995.

18. Pancharuniti N, Lewis CA, Sauberlich HE, Perkins LL, Go RC, Alvarez $\mathrm{JO}$, et al. Plasma homocyst(e)ine, folate, and vitamin B-I2 concentrations and risk for early-onset coronary artery disease. Am J Clin Nutr 1994;59:940-948.

19. Weikert C, Dierkes J, Hoffmann K, Borger K, Drogan D, KlipsteinGrobusch K, et al. B vitamin plasma levels and the risk of ischemic stroke and transient ischemic attack in a German cohort. Stroke 2007;38:2912-29I8. 20. The World Health Organization. Conclusions of a WHO Technical Consultation on folate and vitamin BI2 deficiencies. Food Nutr Bull 2008;29(2).

2I. Howson C, Christianson A, Modell B. Controlling Birth Defects: Reducing the Hidden Toll of Dying and Disabled Children in LowIncome Countries | Disease Control Priorities Project. December 2008. [Accessed 2010 September 23]. Available at: http://www.dcp2.org/ file/230/dcpp-twpcongenitaldefects_web.pdf

22. Berry RJ, Li Z, Erickson D, Li S, Moore CA, Wong $\mathrm{H}$, et al. Prevention of neural-tube defects with folic acid in China. China-U.S. Collaborative Project for Neural Tube Defect Prevention. N Engl J Med 1999;34|:| $485-1490$.

23. Allen LH. How common is vitamin B-12 deficiency? Am J Clin Nutr 2009;9(suppl):693S-696S.

24. McLean E, Benoist B, Allen L. Review of the magnitude of folate and vitamin BI2 deficiencies worldwide. Food Nutr Bull 2008;29:S38-S5I. 25. Resano E, Méndez I, Shamah T, Rivera JA, Sepúlveda J. Methods of the National Nutrition Survey 1999. Salud Publica Mex 2003; 45 suppl 4:S558-S564.

26. Villalpando S, Montalvo-Velarde I, Zambrano N, García-Guerra Armando, Ramírez-Silva Cl, Shamah-Levy T, et al. Vitamins A, and C and folate status in mexican children under 12 years and women 12-49 years: A probabilistic national survey. Salud Publica Mex 2003; 45 suppl 4:S508-S519.

27. Duque X, Flores-Hernández S, Flores-Huerta S, Méndez-Ramírez I, Muñoz S, Turnbull B, et al. Prevalence of anemia and deficiency of iron, folic acid, and zinc in children younger than 2 years of age who use the health services provided by the Mexican Social Security Institute. BMC Public Health 2007; 7:345.

28. Black AK, Allen LH, Pelto GH, de Mata MP, Chávez A. Iron, vitamin $\mathrm{B}-\mathrm{I} 2$ and folate status in Mexico: associated factors in men and women and during pregnancy and lactation. J Nutr 1994; I 24: I I79- I I 88. 29. Allen L. Folate and Vitamin $B_{12}$ Status in the Americas. Nutrition Reviews 2004; 62,(6):S29-S33.

30. Palma O, Shamah T, Franco A, Olaiz G, Méndez I, et al. Metodología. En: Encuesta Nacional de Salud y Nutrición (ENSANUT-2006).

Cuernavaca, México: Instituto Nacional de Salud Pública, 2006:19-33. 
31. Ramírez Cl, Mundo V, Rodríguez SC, Vizuet NI, Hernández N, Jiménez A. Encuestas dietéticas: Recordatorio de 24 horas y Frecuencia de consumo de alimentos. En: Manual de procedimientos para proyectos de nutrición. Cuernavaca, México: Instituto Nacional de Salud Pública, 2006. 32. Safdie M, Barquera S, Porcayo M, Rodríguez S, Ramírez C, Rivera J, et al. Bases de datos del valor nutritivo de los alimentos. Compilación del Instituto Nacional de Salud Pública. Cuernavaca, Morelos: Instituto Nacional de Salud Pública, 2004.

33. Rodriguez-Ramirez S, Mundo-Rosas V, Jiménez-Aguilar A, ShamahLevy T. Methodology for the analysis of dietary data from the Mexican National Health and Nutrition Survey 2006. Salud Publica Mex 2009; 5 I suppl 4: S540-S550.

34. Instuto Nacional de Estadística y Geografía (INEGI). Síntesis metodológica del XII Censo General de Población y Vivienda 2000. p.9. Página de Internet: http://www.inegi.org.mx/est/contenidos/Proyectos/ ccpv/cpv2000/default.aspx

35. Allen L, Rosado JL, Casterline JE,Martínez H, Lopez P, Muñoz E, et al. Vitamin $B / 2$ deficiency and malabsoption are highly prevalent in rural Mexican communities. Am J Clin Nutr 1995; 62:1013-1019.

36. Luqueño V, López-Vidal Y, Calva JJ, Ruíz-Palacios GM. Serum antibody response to Helicobacter pylori in a cohort of Mexican children. Microbiol Ecol 1991;4:S19.
37. Gilman RH, Marquis GS, Miranda E, Vestegui M, Martínez H. Rapid reinfection by Giárdia lambia after treatment in a hyperendemic third world comunity. Lancet 1988: I:343-346.

38. Casterline JE, Allen LH, Ruel MT. Vitamin BI2 deficiency is very prevalent in lactating Guatemalan women and their infants at three months postpartum. J Nutr 1997;127:1966-1972.

39. Cunningham L, Blanco A, Rodriguez S, Ascencio M. Prevalencia de anemia, deficiencia de hierro y folatos en niños menores de siete años. Costa Rica, 1996. Arch Latinoam Nutr 2001;51:37-43.

40. Garcia-Casal MN, Osorio C, Landaeta M, Leets I, Matus P, Fazzino F, et al. High prevalence of folic acid and vitamin BI2 deficiencies in infants, children, adolescents and pregnant women in Venezuela. Eur J Clin Nutr 2005:59:1064-1070

4I. Green R. Indicators for assessing folate and vitamin B 2 status and for monitoring the efficacy of intervention strategies. Food Nutr Bull 2008;29:S52-S63.

42. Organización Panamericana de la Salud. Fortificación de harinas con Hierro, ácido fólico y vitamina BI2. Informe de la reunión regional. Washington, DC: OPS, 2004.

43. Molloy A, Kirke P, Brody I, Scott J, Mills J. Efects of folate and vitamin $B \mid 2$ deficiencies during pregnancy on fetal, infant, and child development. Food Nutr Bull 2008;29(2):SIOI-SIII. 